\title{
PENGARUH RETAIL SERVICE QUALITY TERHADAP MINAT BERKUNJUNG ULANG MALL Di SURABAYA MELALUI PERCEIVED QUALITY DAN CUSTOMER SATISFACTION SEBAGAI VARIABEL INTERVENING
}

\author{
Edwin Japarianto \\ Program Studi Manajemen, Fakultas Ekonomi, Universitas Kristen Petra \\ J1. Siwalankerto 121-131, Surabaya 60236 \\ E-mail: edwinj@petra.ac.id
}

\begin{abstract}
Abstrak: Perkembangan mall berdampak pada semakin meningkatnya pengunjung mall setiap tahun dan juga berdampak pada semakin tingginya persaingan dalam dunia tersebut khususnya di daerah Surabaya. Salah satu cara untuk dapat terus bersaing dan menigkatkan minat berkunjung ulang pengunjung ialah meningkatkan kualitas layanan. Meningkatkan kualitas layanan dapat membangun persepsi pelanggan terhadap mall tersebut yang nantinya akan berdampak pada kepuasan pengunjung serta akan meningkatkan minat pengunjung dalam melakukan kunjungan kembali. Penelitian ini bertujuan untuk menganalisa pengaruh Retail Service Quality terhadap Minat Berkunjung Ulang yang di-intervening oleh Perceived Quality dan Customer Satisfaction pada mall. Penelitian ini dilakukan dengan menyebarkan angket / kuesioner kepada 100 orang responden yang telah berkunjung ke mall. Metode penelitian yang digunakan merupakan metode analisa kuantitatif dengan menggunakan Smart PLS.Hasil dari penelitian menunjukkan Retail Service Quality berpengaruh signifikan terhadap Minat Berkunjung Ulang dan variabel Perceived Quality dan Customer Satisfaction mengintervening hubungan Retail Service Quality dan Minat Berkunjung Ulang.
\end{abstract}

Kata kunci: Customer satisfaction; minat berkunjung ulang; perceived quality; retail service quality.

\begin{abstract}
The Effect of Retail Service Quality on Revisit Intention in Mall Mall Through Perceived Quality and Customer Satisfaction as Intervening Variable. The development of mall impacted on increasing mall visitors every year and also impact on the increasing competition in this industry, especially in the area of Surabaya. One way to continue to compete and to increase the interest of visitors is to improve the quality of service. Improving the quality of services can build perceptions of the mall which will impact on visitor satisfaction and will increase the interest of visitors in making a revisit intention.This study aims to analyze the effect of Retail Service Quality on Intercontinental Visits which are intervened by Perceived Quality and Customer Satisfaction at mall. This research was conducted by distributing questionnaires to 100 respondents who have visited mall. The research method used is quantitative analysis method using Smart PLS.The result of the research shows that Retail Service Quality has significant effect on Visiting Interest and Perceived Quality and Customer Satisfaction variables interfere with Retail Service Quality and Revisit Intention.
\end{abstract}

Keywords: Customer satisfaction; perceived quality; retail service quality; revisit intention.

\section{PENDAHULUAN}

Dengan populasi sebesar \pm 2.853 .661 jiwa, kota Surabaya menjadi kota dengan penyumbang penduduk terbesar ke-2 di Indonesia dengan presentase mendekati $1,5 \%$ dari total 255.708 .785 jiwa di seluruh Indonesia dibawah ibukota Jakarta yang berada di urutan tertinggi. Statistik ini juga yang membuat Surabaya banyak diminati oleh para investor dalam pengembangan pembangunan mall di Surabaya.

Dengan jumlah populasi sebanyak itu, mall dapat terus tumbuh sebagai akibat dari perkembangan jumlah penduduk. Ditambah juga jumlah pengunjung mall perharinya berada di angka antara 35.000 45.000 pada hari biasa dan 50.000-60.000 pengunjung pada akhir pekan yang memiliki minat berkunjung ulang yang berbeda-beda ditiap mallnya dengan banyak pertimbangan yang dimiliki oleh konsumen sebagai dampak dari strategi yang dilakukan oleh pihak mall itu sendiri.

Sampai saat ini sudah terdapat 11 mall di wilayah Surabaya, dengan beberapa pembagian kelas, middle up, middle middle dan middle low. Terdapat enam mall yang berada di kelas middle up yaitu diantaranya; Pakuwon mall, Lenmarc, Ciputra World, Grand City Mall, Tunjungan plaza dan Galaxy mall. Dan terdapat dua mall yang masuk dalam kelas middle middle yaitu Royal plaza dan Supermall, dan sisanya masuk dalam kelas middle low, dengan daftar sebagai berikut; PTC,CITO dan Delta plaza, yang juga menunjukan perkembangan pada pembangunan mall di Surabaya termasuk baik dan stabil mengikuti trend.

Menurut Dabholkar (1996) retail service quality memiliki lima dimensi yaitu physical aspects, problem solving, policy, reliability, personal interaction. 
Dimensi pertama physical aspects yang meliputi segala macam fasilitas dan peralatan yang mempengaruhi kualitas layanan. Dimensi kedua yaitu reliability yang mencakup konsistensi ritailer dalam memberikan layanan pada pelanggan terutama mengenai janji yang diberikan perusahaan. Dimensi ketiga yaitu problem solving yang merupakan penilaian terhadap kemampuan retailer dalam menyelesaikan masalah seperti retur barang, penukaran dan lainlain. Dimensi ketiga yaitu policy yang merupakan kebijakan-kebijakan yang dibuat oleh peretail demi kenyamanan pelanggan, dan dimensi yang terakhir adalah personal interaction yang menjadi kemampuan peretail untuk menjalin hubungan dengan pelanggan hingga dapat memuaskan pelanggan.

Menurut Tjiptono (1996), Kualitas layanan ritel akan memberikan suatu dorongan kepada konsumen untuk menjalin ikatan yang erat dengan mall itu sendiri. Dalam jangka panjang, ikatan ini memungkinkan mall untuk memahami lebih dalam customer expectation serta customer needs yang akan berdampak pada customer satisfaction. Dengan demikian, mall akan dapat dengan mudah menentukan peningkatan retail service quality dimana mall dapat memaksimumkan pengalaman konsumen yang menyenangkan dan meminimumkan pengalaman konsumen yang kurang menyenangkan. Dan dari sinilah, kita bisa mengetahui bahwa retail service quality memiliki hubungan yang erat dengan customer satisfaction. Dengan demikian Mall terus berusaha menjalin ikatan dengan para pengunjungnya dengan berbagai macam service dan fasilitas yang disediakan di dalam maupun luar mall.

Perceived Quality merupakan persepsi konsumen terhadap keseluruhan kualitas atau jasa layanan dengan maksud yang diharapkan konsumen (David A. Aaker, 1997). Pelanggan menganggap kualitas yang dirasakan sebagai konsep yang lebih spesifik berdasarkan fitur produk dan layanan. Perusahaan dapat memiliki tingkat kontrol atas kualitas (Asma Saleem, Abdul Ghafar, Muhammad Ibrahim \& Ahmed, 2015) Dengan demikian, disarankan ketika persepsi kualitas dianggap sebagai penilaian keseluruhan, maka kualitas yang dirasakan dipahami sebagai sumber kepuasan (Llusar et al., 2001).

Menurut Jamaluddin pada tahun 2013 Perceived Quality mempunyai pengaruh yang signifikan terhadap kepuasan konsumen. Pengaruhnya adalah positif artinya semakin tinggi Perceived Quality maka semakin tinggi kepuasan konsumennya. Tingkat keberhasilan pelayanan di Mall mall ditentukan oleh perceived quality ataupun penilaian subjektif pengunjung terhadap retail service quality, sehingga tingkat keberhasilan suatu layanan dapat diindentifikasi dengan mengukur tingkat customer satisfaction yang juga akan mempengaruhi perceived quality konsumen terhadap retail service quality di mall tersebut. Selain itu untuk memperoleh strategi pelayanan yang berorientasi pada customer satisfaction, dan untuk menjaga minat berkunjung ulang konsumen, tingkat customer satisfaction sangat penting untuk diketahui.

Berdasarkan latar belakang diatas, maka penelitian ini akan meneliti tentang pengaruh retail service quality terhadap minat berkunjung ulang pada mall di Surabaya melalui perceived quality dan customer satisfaction. Peneliti berharap penelitian ini dapat memberikan gambaran lebih mengenai pengaruh dari Retail Service Quality terhadap kepuasan pelanggan dan dapat memberikan persepsi yang baik pada Mall yang akan berdampak juga pada minat para konsumen untuk berkunjung ulang ke Mall.

\section{LANDASAN TEORI}

\section{Retail Service Quality}

Dabholkar, Pratibha, Dayle Thrope dan Joseph Rentz (1996) mengungkapkan dan mengkritik bahwa model SERVQUAL belum berhasil diadaptasi dan divalidasi untuk mengidentifikasi persepsi pelanggan dari retail service quality, dimana retail tersebut menjual berbagai barang dan jasa, meskipun model SERVQUAL telah secara empiris diuji dalam beberapa penelitian.

\section{Dimensi Retail Service Quality}

Menurut Dabholkar (1996) terdapat 5 dimensi yang digunakan sebagai cara untuk mengukur retail service quality yaitu:

\section{Physical aspects}

Penampilan fasilitas fisik dan kenyamanan yang ditawarkan kepada pelanggan berkaitan dengan layout fasilitas fisik juga termasuk material jasa dan juga meliputi peralatan dan perlengkapan yang digunakan perusahaan dalam menyampaikan kualitas layanan.

\section{Reliability}

Pada prinsipnya sama dengan dimensi reliabilitas pada model SERVQUAL. Hanya saja terdapat 2 sub-dimensi, yaitu memenuhi janji (keeping promise) dan memberikan layanan dengan tepat. Janji yang di lontarkan oleh perusahaan harus benarbenar ditepati dengan kepastian waktu yang telah ditentukan.

\section{Personal interaction}

Mengacu pada kemampuan karyawan jasa dalam menumbuhkan kepercayaan pelanggan dan sikap sopan/suka membantu. Pada prinsipnya, dimensi 
ini merefleksikan cara karyawan memperlakukan para pelanggan dan meningkatkan kepercayaan diri pelanggan, pengetahuan karyawan mengenai produk dan jasa yang dijual, perlakuan karyawan yang tidak pernah merasa sibuk untuk membantu pelanggan, serta perhatian personal karyawan.

4. Problem solving

Karyawan telah terlatih untuk mengatasi masalah yang mungkin terjadi seperti komplain dan retur secara langsung dan sigap, serta karyawan menunjukan ketertarikan untuk memecahkan masalah.

5. Policy

Policy atau kebijakan dari perusahaan meliputi kenyamanan dan keamanan dalam melakukan pembayaran, jam operasional, pilihan metode pembayaran, kartu kredit, dan lahan parkir.

\section{Perceived quality}

Perceived quality memiliki peran penting dalam proses membangun minat berkunjung ulang terhadap sebuah mall. Sependapat dengan Rangkuti (2004) persepsi terhadap kualitas suatu produk ataupun jasa dapat menentukan nilai dari produk atau jasa tersebut dan berpengaruh secara langsung kepada keputusan pembelian konsumen dan loyalitas mereka terhadap sebuah merek, perceived quality sebuah mall dapat menjadi sebuah alasan penting pengunjung untuk melakukan kunjungan ulang serta mall mana yang menjadi pertimbangan yang akan mempengaruhi pengunjung dalam memutuskan mall yang akan dikunjungi.

Perceived quality memiliki hubungan yang erat dengan harapan pelanggan karena kualitas keseluruhan layanan dan produk akan di persepsikan oleh pelanggan sama dengan maksud yang mereka harapkan. Sependapat dengan Aaker (1991) yang berpendapat bahwa perceived quality merupakan pandangan secara keseluruhan dari pelanggan mengenai kualitas produk dan layanan yang sesuai dengan harapan mereka. Persepsi dari pelanggan yang akan selalu berbeda satu sama lain akan melibatkan apa yang penting bagi setiap individu pelanggan, karena pelanggan memiliki kepentingan yang berbeda-beda kepada produk atau jasa.

Mall dengan perceived quality yang positif akan berdampak pada timbulnya minat berkunjung pelanggan dan dapat menciptakan loyalitas terhadap mall tersebut, karena perceived quality merupakan persepsi subjektif dari konsumen dapat dikatakan jika perceived quality yang dimiliki pengunjung mall negatif, mall tersebut tidak akan disukai. Berlaku juga sebaliknya, jika perceived quality pengunjung positif, mall akan disukai. Sependapat dengan Darmadi (2004) yang berpendapat bahwa Perceived quality yang positif akan mendorong keputusan pembelian dan menciptakan loyalitas terhadap produk tersebut, karena perceived quality merupakan persepsi konsumen maka dapat diramalkan jika perceived quality pelanggan negatif, produk tidak akan disukai dan tidak akan bertahan lama di pasar. Sebaliknya, jika perceived quality pelanggan positif, produk akan disukai.

\section{Dimensi Perceived Quality}

Menurut Darmadi (2004) dimensi perceived quality adalah:

1. Kinerja

Melibatkan berbagai karakteristik operasional utama.

2. Pelayanan

Mencerminkan kemampuan memberikan pelayan kepada produk tersebut.

3. Ketahanan

Mencerminkan umur ekonomis dari produk atau jasa tersebut.

4. Keandalan

Konsistensi dari kinerja yang dihasilkan suatu produk dari satu pembelian ke pembelian berikutnya.

5. Karakteristik produk

Bagian-bagian tambahan dari produk yang memberi penekanan bahwa perusahaan memahami kebutuhan pelanggannya yang dinamis sesuai perkembangan.

6. Kesesuaian dengan spesifikasi.

Merupakan pandangan mengenai kualitas proses manufaktur (tidak cacat produk) sesuai dengan spesifikasi yang telah teruji.

7. Hasil

Mengarah kepada kualitas yang dirasakan melibatkan enam dimensi sebelumnya.

\section{Customer Satisfaction}

Menurut Kotler dan Keller (2009),kepuasan didefinisikan sebagai perasaan pelanggan yang puas atau kecewa atas hasil dari membandingkan kinerja yang dipersepsikan produk (atau hasil) dalam kaitannya dengan ekspektasi pelanggan. Dengan definisi tersebut dapat dikatakan kepuasan merupakan sebuah hasil perbandingan antara kinerja atau hasil yang didapat dengan ekpektasi yang diharapkan pelanggan yang menjadikan perasaan puas atau kecewa dari pelanggan itu sendiri, dengan kata lain perasaan yang di miliki oleh pelanggan adalah sebuah tujuan akhir dari sebuah perusahaan karena juga akan mencerminkan kepuasan pelanggan, namun juga dapat mencerminkan kekecewaan, sependapat dengan Fornell (1992) yang berpendapat bahwa Customer satisfac- 
tion/dissatisfaction merupakan evaluasi keseluruhan setelah pembelian produk atau jasa yang dilakukan pelanggan.

Kepuasan pelanggan menurut Zeithaml, Bitner dan Dwayne (2009, p.104) merupakan penilaian pelanggan atas produk ataupun jasa dalam hal menilai apakah produk atau jasa tersebut telah memenuhi kebutuhan dan ekspektasi pelanggan sebagaimana menurut Cronin dan Tailor (1992;57) kepuasan pelanggan merupakan faktor utama dalam menilai kualitas pelayanan, dimana konsumen menilai kinerja pelayanan yang diterima dan yang dirasakan secara langsung terhadap suatu pelayanan. Customer Satisfaction penting untuk di perhatikan oleh sebuah mall, karena berbagai layanan dan aktifitas yang dilakukan mall akan mempengaruhi kepuasan pelanggan terhadap mall tersebut.

Kepuasan pelanggan menjadi salah satu faktor kunci sebuah perusahaan untuk dapat terus berjalan, namun kepuasan pelanggan tidak mudah untuk dicapai sebagaimana pelanggan juga tidak memiliki definisi mutlak untuk menentukan apakah mereka puas atau tidak dengan layanan yang disediakan oleh Perusahaan. Ditambah lagi menurut (Ihtiyar, Ahmad, \& Osman, 2014) perusahaan harus menyadari bahwa pelanggan mereka menginginkan keuntungan yang berbeda-beda karena setiap pelanggan memiliki kebutuhan yang berbeda-beda yang menyebabkan pengukuran yang dilakukan pada Customer satisfaction tidak mudah dicapai.

\section{Dimensi Customer satisfaction}

Zeithaml (2009) mengatakan terdapat 3 dimensi dalam Customer satisfaction yang digunakan dalam penelitian ini yaitu:

1. Satisfaction as fulfillment.

Pelanggan akan merasa puas apabila kebutuhan mereka tercukupi atau terpenuhi. Disaat pelanggan merasa kebutuhannya sudah terpenuhi dengan cukup baik, maka kecenderungan pelanggan akan lebih bersifat acuh dan memiliki respon pelanggan yang pasif. Sehingga contentment merupakan komponen dari satisfaction as fulfillment dan juga menjadi dampak dari satisfaction as fulfillment.

2. Satisfaction as pleasure.

Pelanggan merasa sangat senang dapat bertransaksi dengan perusahaan. Seluruh kebutuhannya tercukupi dan sangat memuaskan pelanggan. Satisfaction as pleasure merupakan gabungan dari satisfaction as delight, karena pelanggan merasa senang dan puas dan membuat perusahaan tidak memiliki citra yang buruk di mata pelanggan. Sehingga satisfaction as pleasure dan satisfaction as delight merupakan hasil hubungan yang positif antara perusahaan dengan pelanggan.

\section{Satisfaction as relief}

Dalam beberapa situasi, di mana konsumen mengesampingkan hal negatif mengarah pada kepuasan, konsumen dapat mengaitkan kelegaan terhadap hal tersebut dengan kepuasan yang dirasakan.

\section{Minat berkunjung ulang}

Menurut Schiffman dan Kanuk (2007:201) minat merupakan aktivitas psikis yang timbul karena adanya perasaan dan pikiran terhadap suatu barang atau jasa yang diinginkan, secara singkat minatlah yang menyebabkan timbulnya rasa ingin memiliki, merasakan ataupun mengunjungi. Dalam penelitian ini akan lebih berfokus pada minat seseorang dalam keinginan mereka mengunjungi sebuah tempat.

Meninjau kembali minat kunjungan telah dianggap sebagai salah satu ilmu penting dalam pemasaran dan telah menjadi salah satu faktor penting dalam pengimplenetasiannya di dunia wisata. Menyinggung dunia wisata, Sinclair (2007:22) berpendapat tentang jenis-jenis Pariwisata yang telah dikenal, antara lain: Herritage tourism (wisata peninggalan), Healty tourism (wisata kesehatan), Sport tourism (wisata olahraga), Shopping tourism (wisata belanja), Industry tourism (wisata industri), Sea tourism (wisata laut), Natural tourism (wisata alam), Honeymoon tourism (wisata berbulan madu). Mengacu pada pendapat Sinclair, salah satu dari jenis-jenis wisata tersebut adalah shopping tourism (wisata belanja). Peran shopping tourism/wisata belanja sebagai tujuan utama untuk bepergian, termasuk alasan utama untuk popularitas dan pertumbuhan. Belanja sebagai bentuk pariwisata pertama dalam kerangka produk yang dibeli, dipilih tujuan, dan keuntungan harga/ nilai. Wisata belanja pada jaman saat ini / modern adalah wisata belanja pada mall (Mardiyana, Wibowo, \& Andari, 2012).

Baker dan Crompton (2000) berpendapat bahwa minat kunjungan ulang adalah niat yang dimiliki pengunjung untuk mengunjungi suatu tempat dalam kurun waktu tertentu dan kesediaan mereka untuk sering melakukan kunjungan kembali ke tempat tersebut. Dengan meningkatkan minat berkunjung ulang dan menghasilkan minat berkunjung yang tinggi pada pelanggannya akan menjadi sebuah hal positif yang akan mendatangkan profit bagi perusahaan terlebih jika dilakukan terus menerus. Minat berkunjung ulang seseorang timbul karena adanya keinginan untuk menikmati kembali produk berupa jasa yang ditawarkan perusahaan. Sejalan dengan pendapat yang diungkapkan oleh Kozak (2001) minat berkunjung ulang merupakan tindakan nyata dalam menanggapi perilaku tertentu yang pada umumnya mengacu pada keinginan pengunjung untuk mengunjungi suatu tempat tujuan atau tempat tujuan lain. 
Pelanggan akan mempertimbangkan beberapa hal dalam menimbulkan minat berkunjung ulang. Penelitian ini akan menggunakan dua indikator dalam mengukur minat berkunjung ulang yang diungkapkan oleh Chung-Hslen Lin (2012)

1. Intention To Recommend (Keinginan untuk merekomendasikan kepada orang lain)

2. Intention To Revisit (Keinginan untuk kembali berkunjung)

\section{Model Penelitian}

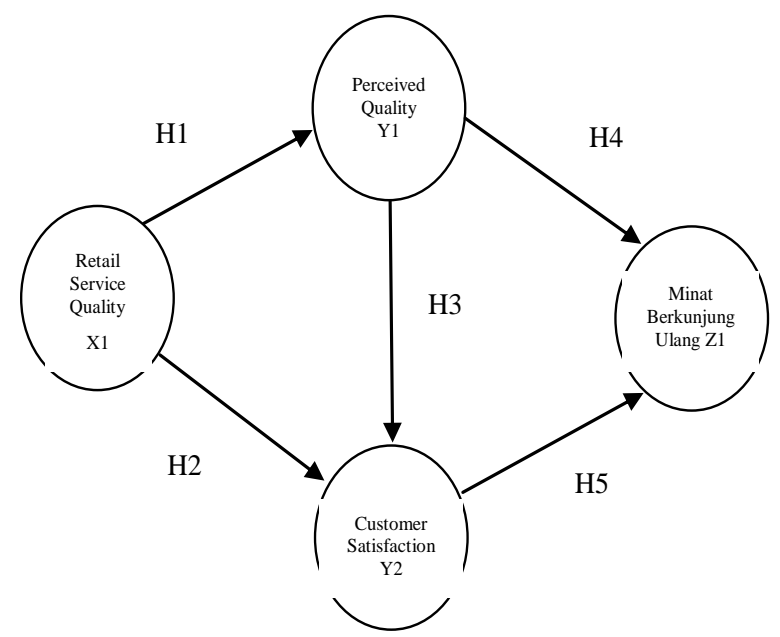

Gambar 1. Model Penelitian

\section{Hipotesa}

H1: Retail Service Quality berpengaruh terhadap Perceived Quality

H2: Retail Service Quality berpengaruh terhadap Customer Satisfaction

H3: Perceived Quality berpengaruh terhadap Customer Satisfaction

H4: Perceived Quality berpengaruh terhadap Minat berkunjung ulang

H5: Customer Satisfaction berpengaruh terhadap Minat berkunjung ulang

\section{METODOLOGI PENELITIAN}

\section{Populasi}

Populasi adalah gabungan seluruh elemen yang memiliki serangkaian karakteristik serupa, yang mencakup semesta untuk kepentingan masalah riset pemasaran (Malhotra, 2004). Pendapat lainnya mengatakan bahwa populasi adalah wilayah generalisasi yang terdiri dari obyek atau subyek yang mempunyai kualitas dan karakteristik tertentu yang diterapkan oleh peneliti untuk dipelajari dan kemudian ditarik kesimpulannya (Sugiyono, 2009). Populasi dalam penelitian ini adalah pengunjung Mall di Surabaya.

\section{Sampel}

Sampel adalah bagian dari jumlah dan karakteristik yang dimiliki oleh populasi tersebut (Sugiyono, 2009). Dengan melakukan penelitian kepada sebagian dari populasi, diharapkan bahwa hasil yang didapat mampu menggambarkan populasi yang bersangkutan. Syarat utama sampel yang baik yaitu mampu mewakili ciri dan karakteristik populasi dengan bias yang terlalu kecil.

Teknik pengambilan sampel pada penelitian ini menggunakan teknik non probability sampling, dimana semua populasi tidak memiliki peluang yang sama untuk menjadi responden dan pengambilan sampel didasarkan pada pertimbangan peneliti (Simamora, 2002). Jenis non probability sampling yang digunakan dalam penelitian ini adalah purposive sampling dimana peneliti melakukan penilaian untuk memilih anggota populasi yang dinilai paling tepat sesuai dengan kriteria tertentu. pengunjung yang menjadi sampel sebagai responden dalam penelitian ini adalah pengunjung yang berdomisili di Surabaya dan pernah mengunjungi Mall di Surabaya setidaknya dua kali dalam kurun waktu tiga bulan terakhir pada saat pengisian kuesioner (januari 2018-maret 2018) dan melakukan interiaksi dengan karyawan mall (satpam,resepsionis,petugas parkir,dll).

\section{Definisi Operasional Variabel}

\section{Retail Service Quality (XI)}

a. Physical Aspect

Segala unsur yang berada didalam mall yang bersifat tangible dan dapat membantu memberikan kenyamanan bagi pengunjung

\section{b. Reliability}

Kemampuan mall dalam menepati janji yang telah diutarakan

\section{c. Personl Interaction}

Mengacu pada kemampuan karyawan mall dalam menumbuhkan kepercayaan pelanggan dan sikap sopan/suka membantu.

\section{d. Problem Solving}

Karyawan mall telah terlatih untuk mengatasi masalah yang mungkin terjadi seperti komplain dan retur secara langsung dan sigap, serta karyawan menunjukan ketertarikan untuk memecahkan masalah.

e. Policy

Policy atau kebijakan dari pihak mall meliputi kenyamanan dan keamanan dalam melakukan pembayaran, jam operasional, pilihan metode pembayaran, kartu kredit, dan lahan parkir.

2. Perceived Quality (YI)

a. Kinerja

Penilaian mall yang melibatkan karakteristik utama yang dimiliki mall 
b. Pelayanan

Mencerminkan kemampuan mall dalam memberikan pelayan

c. Ketahanan

Berhubungan dengan jangka waktu atau masa guna produk dan jasa yang digunakan dalam masa waktu tertentu. Dimensi ketahanan tidak digunakan dalam penelitian ini karena tidak sesuai dengan objek penelitian.

d. Keandalan

Konsistensi dari kinerja yang dihasilkan suatu produk dari satu pembelian ke pembelian berikutnya.

e. Karakteristik Produk

Sifat atau ciri khusus yang dimiliki sebuah mall yang dapat menjadi salah satu faktor pembeda

f. Kesesuaian Dengan Spesifikasi

Merupakan kesesuaian mutu jasa yang diberikan perusahaan kepada pelanggan. Dimensi kesesuaian dengan spesifikasi tidak digunakan dalam penelitian ini karena tidak sesuai dengan objek penelitian

g. Hasil

Merupakan Manfaat atau benefit yang diterima oleh pelanggan

3. Customer Satisfaction (Y2)

a. Satisfaction as Fulfillment

Sebuah kepuasan yang dimiliki pengunjung saat kebutuhan terpenuhi

b. Satisfaction as Pleasure

Sebuah kepuasan yang dimiliki pengunjung saat mereka merasa sangat senang atau sangat bahagia

c. Satisfaction as Relief

Pengunjung dapat mengesampingkan hal negatif mengarah pada kepuasan, pengunjung dapat mengaitkan kelegaan terhadap hal tersebut dengan kepuasan yang dirasakan

4. Minat Berkunjung Ulang (Zl)

a. Intention To Recommend

Keinginan pengunjung untuk melakukan rekomendasi kepada kerabat

b. Intention To Revisit

Keinginan pengunjung untuk melakukan kunjungan ulang

\section{ALAT ANALISA}

\section{Path Analysis}

Pengujian hipotesis yang ada pada penelitian ini dilakukan dengan menggunakan teknik path analysis untuk menujukkan adanya hubungan yang kuat dengan variabel-variabel yang diuji. Teknik path analysis digunakan untuk melukiskan dan menguji model hubungan antar variabel yang berbentuk sebab akibat (Sugiyono, 2007). Teknik ini merupakan pengembangan korelasi yang diurai menjadi beberapa interpretasi akibat yang ditimbulkannya.

Pengujuan statistik pada model path analysis dilakukan dengan menggunakan metode partial least square. Partial Least Square (PLS) adalah bagian dari SEM. PLS merupakan teknik terbaru yang banyak diminati karena tidak membutuhkan distribusi normal atau dapat dikatakan sebuah penelitian dengan jumlah sampel yang sedikit. Salah satu kelebihan PLS-SEM adalah mampu menangani model yang kompleks dengan multiple variabel eksogen dan endogen dengan banyak indikator, dapat digunakan pada sampel dengan jumlah kecil, dan data distribusi yang condong (Abdillah \& Hartono, 2015).

\section{T-test}

Di dalam penelitian ini terdapat variabel intervening yaitu penghubung antara variabel dependen dan variabel independen. Pengujian hipotesis mediasi (variabel intervening) dapat dilakukan dengan prosedur $t$-test. Pengujian $t$-test digunakan untuk mendapatkan nilai t-statistik yang diperlukan apabila peneliti ingin melakukan uji hipotesis, sehingga peneliti dapat mengatakan pengaruh sebuah variabel dapat dikatakan memiliki pengaruh yang signifikan atau tidak. T-test dilakukan dengan menggunakan metode bootstrapping.

Metode bootstrapping adalah suatu proses pengujian re-sampling yang dilakukan oleh sistem komputer untuk mengukur akurasi pada sample estimate. Bootstraping digunakan untuk mengukur akurasi pada sample. Apabila nilai bootstrap lebih dari (>) 1.96 maka dinyatakan bahwa variabel tersebut memiliki pengaruh yang signifikan sedangkan apabila nilai bootstrap lebih rendah $(<)$ dari 1.96, maka dinyatakan pengaruh variabel tersebut lemah (Abdillah \& Hartono, 2015).

\section{ANALISA DAN PEMBAHASAN}

\section{Evaluasi Path Coefficient dan Coefficient of deter- mination}

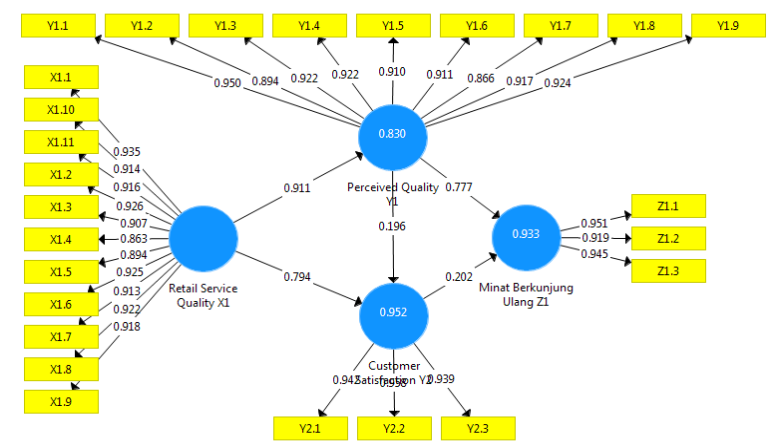

Gambar 2. Path Coefficient dan Coefficient of determination 
Pada analisa path coefficient ini telah terbukti bahwa Perceived Quality merupakan variable intervening yang dimana memperkuat hubungan antara Retail Service Quality dan Minat berkunjung ulang. Hubungan antara Retail Service Quality dan Minat berkunjung ulang melalui variable Perceived Quality sebesar 0.707 yang dimana merupakan hasil perkalian antara 0.911 dan 0.777 .

Pada analisa path coefficient ini telah terbukti bahwa Perceived Quality dan customer satisfaction merupakan variable intervening yang dimana memperkuat hubungan antara Retail Service Quality dan Minat berkunjung ulang sebesar 0.036 yang dimana merupakan hasil perkalian antara 0.911 dan 0.196 dan 0.202 .

Pada analisa path coefficient ini telah terbukti bahwa Customer Satisfaction merupakan variable intervening yang dimana memperkuat hubungan antara Retail Service Quality dan Minat berkunjung ulang. Hubungan antara Retail Service Quality dan Minat berkunjung ulang melalui variable Customer Satisfaction sebesar 0.160 yang dimana merupakan hasil perkalian antara 0.794 dan 0.202 .

\section{T-statistic}

Tabel 1. T-statistic

\begin{tabular}{|l|l|l|l|l|l|}
\hline & $\begin{array}{l}\text { Original } \\
\text { Sample } \\
(\mathrm{O})\end{array}$ & $\begin{array}{l}\text { Sample } \\
\text { Mean } \\
(\mathrm{M})\end{array}$ & $\begin{array}{l}\text { Standard } \\
\text { Deviation } \\
(\mathrm{STDEV})\end{array}$ & $\begin{array}{l}\mathrm{T} \text { Statistics } \\
(\mid \mathrm{O} / \mathrm{STDEV})\end{array}$ & $\begin{array}{l}\mathrm{P} \\
\text { Values }\end{array}$ \\
\hline $\begin{array}{l}\text { Customer Satisfaction } \\
\text { (Y2) Minat } \\
\text { Berkunjung Ulang (Z1) }\end{array}$ & 0.202 & 0.219 & 0.088 & 2.305 & 0.022 \\
\hline $\begin{array}{l}\text { Perceived Quality (Y1) } \\
\text { S Customer } \\
\text { Satisfaction (Y2) }\end{array}$ & 0.196 & 0.206 & 0.059 & 3.345 & 0.001 \\
\hline $\begin{array}{l}\text { Perceived Quality (Y1) } \\
>\text { Minat Berkunjung } \\
\text { Ulang (Z1) }\end{array}$ & 0.777 & 0.760 & 0.086 & 9.076 & 0.000 \\
\hline $\begin{array}{l}\text { Retail Service Quality } \\
\text { (X1) > Customer } \\
\text { Satisfaction (Y2) }\end{array}$ & 0.794 & 0.784 & 0.060 & 13.176 & 0.000 \\
\hline $\begin{array}{l}\text { Retail Service Quality } \\
\text { (X1) Perceived }\end{array}$ & & & & & \\
Quality (Y1) & 0.911 & 0.912 & 0.032 & 28.907 & 0.000 \\
\hline
\end{tabular}

Dengan melihat Tabel 1, diatas memiliki arti bahwa nilai original sampel $(\mathrm{O})$ adalah nilai path coefficient yang menunjukan kekuatan pengaruh satu latent variable ke latent variable lainnya. Nilai pada kolom mean (M) menunjukan nilai tengah dari path coefficient. Lalu standar deviasi (STDEV), menunjukkan nilai simpang pada sampel mean. Nilai $T$-statistic untuk melihat nilai $\mathrm{T}$ hitung yang akan digunakan pada pengujian hipotesis.
Tabel 2. Kesimpulan Uji Hipotesis

\begin{tabular}{clc}
\hline Hipotesis & \multicolumn{1}{c}{ Keterangan } & T-statistic \\
\hline $\mathrm{H}_{1}$ & $\begin{array}{l}\text { Retail Service Quality berpengaruh } \\
\text { terhadap Perceived Quality }\end{array}$ & 28.907 \\
$\mathrm{H}_{2}$ & $\begin{array}{l}\text { Retail Service Quality tidak } \\
\text { berpengaruh terhadap Customer } \\
\text { Satisfaction }\end{array}$ & 13.176 \\
$\mathrm{H}_{3}$ & $\begin{array}{l}\text { Perceived Quality berpengaruh } \\
\text { terhadap Customer Satisfaction }\end{array}$ & 3.345 \\
$\mathrm{H} 4$ & $\begin{array}{l}\text { Perceived Quality tidak berpengaruh } \\
\text { terhadap Minat Berkunjung Ulang } \\
\mathrm{H} 5\end{array}$ & $\begin{array}{l}\text { Customer Satisfaction berpengaruh } \\
\text { terhadap Minat Berkunjung Ulang }\end{array}$ \\
\hline
\end{tabular}

1. Pengaruh Retail Service Quality terhadap Perceived Quality memiliki nilai T-statistics 28,907, artinya terdapat pengaruh dari Retail Service Quality terhadap Perceived Quality

2. Pengaruh Retail Service Quality terhadap Customer Satisfaction memiliki nilai T-statistics 13,176, artinya terdapat pengaruh dari Retail Service Qualityterhadap Customer Satisfaction

3. Pengaruh Perceived Quality terhadap Customer Satisfaction memiliki nilai T-statistics 3,345, artinya terdapat tidak terdapat pengaruh dari Perceived Quality terhadap Customer Satisfaction

4. Pengaruh Perceived Quality terhadap Minat Berkunjung Ulangmemiliki nilai T-statistics 9,076, artinya terdapat pengaruh dari Perceived Quality terhadap Minat Berkunjung Ulang

5. Pengaruh Customer Satisfaction terhadap Minat Berkunjung Ulang memiliki nilai T-statistics 2,305, artinya terdapat pengaruh Customer Satisfaction terhadap Minat Berkunjung Ulang

\section{PEMBAHASAN}

\section{Retail Service Quality terhadap Perceived Quality}

Penelitian ini memiliki hasil bahwa Retail Service quality pada Mall mall memiliki pengaruh terhadap Perceived Qualitysecara signifikan dengan nilai uji $T$-statistic $>1.96$ yaitu 28.907 dan $P$ value sebesar 0.000 .

Penelitian ini mempunyai hasil yang menunjukkan bahwa Retail Service quality berpengaruh signifikan terhadap Perceived Qualityyang dimana hal ini sesuai dengan pendapat Bahram (2012) bahwa dalam membentuk Perceived Quality pada sebuah layanan, perusahaan harus dapat meningkatkan kualitas dari layanan tersebut.

Hubungan antara Retail Service quality dan Perceived Quality juga dapat dibuktikan memiliki hubungan yang signifikan dimana hal ini sesuai dengan pendapat Hisam (2016) bahwa dimensi pada 


\section{Retail Service quality secara positif dipengaruhi oleh Perceived Quality.}

Mall telah meningkatkan kualitas layanan ritel dengan menggunakan berbagai dimensi-dimensi didalamnya. Dalam analisa Crosstabulation dimensi, variable-variabel juga menunjukan bahwa pengunjung setuju dengan berbagai macam bentuk layanan yang berkualitas baik dan begitu juga kesetujuan pengunjung dalam mempresepsikan dengan baik berbagai layanan yang dimiliki Mall.

\section{Retail Service Quality terhadap Customer Satisfac- tion}

Penelitian ini memiliki hasil bahwa Retail Service quality dari Mall mall berpengaruh secara signifikan terhadap Customer satisfaction dengan nilai uji T-statistic <1.96 yaitu 13.176 dan $P$ value sebesar 0.000 .

Penelitian ini mempunyai hasil yang menunjukkan bahwa Retail Service quality berpengaruh signifikan terhadap Customer satisfaction yang dimana hal ini sesuai dengan pendapat Zhang, Zhang dan Law Rob, (2013) dimana kepuasan dari pelanggan sangat dipengaruhi oleh lingkungan layanan dan juga sesuai dengan pendapat Hisam, Sanyal dan Ahmad (2016) yang menyatakan Service quality yang dilakukan oleh toko retail akan mempengaruhi Customer satisfaction.

Penelitian ini memiliki hasil yang membuktikan Retail Service Quality pada Mall mall berpengaruh secara signifikan terhadap Customer satisfaction. Upaya Mall mall untuk memberikan kepuasan terhadap pengunjung dengan memberikan fasilitas yang dapat selalu memenuhi kebutuhan pengunjung selama berkunjung ke Mall, kemudian selalu meningkatkan dan memberikan layanan yang sopan dan tanggap kepada pengunjung.

\section{Perceived Quality terhadap Customer Satisfaction}

Penelitian ini memiliki hasil bahwa Perceived Qualitypada Mall mall memiliki pengaruh terhadap Customer satisfaction secara signifikan dengan nilai uji $T$-statistic $>1.96$ yaitu 3.345 dan $P$ value sebesar 0.001 .

Penelitian ini mempunyai hasil yang menunjukkan bahwa Perceived Qualityberpengaruh signifikan terhadap Customer satisfaction yang dimana hal ini sesuai dengan pendapat Saleem, Ghafar, Ibrahim, Yousuf \& Naveed (2015) di mana Perceived Quality memiliki pengaruh signifikan positif terhadap Customer satisfaction. Menurut Bahram, Ali dan Majid (2012) Perceived Quality memiliki pengaruh secara langsung dan signifikan terhadap kepuasan pelanggan yang juga sejalan dengan hasil penelitian ini.
Perceived Quality terhadap Minat Berkunjung Ulang

Penelitian ini memiliki hasil bahwa Perceived Quality pada Mall mall berpengaruh secara signifikan terhadap Minat Berkunjung Ulang dengan nilai uji $T$ statistic $>1.96$ yaitu 9.076 dan $P$ value sebesar 0.000 .

Penelitian ini mempunyai hasil yang menunjukkan bahwa Perceived quality berpengaruh signifikan terhadap Minat Berkunjung Ulangyang dimana hal ini sesuai dengan pendapat Aziz, Ariffin, Omar dan Evin (2012) yang menyatakan pengunjung yang puas dengan kinerja dan layanan sebuah perusahaan yang merupakan dimensi dari Perceived quality akan membuat pengunjung itu ingin melakukan kunjungan kembali di masa mendatang.

\section{Customer Satisfaction terhadap Minat Berkun- jung Ulang}

Penelitian ini memiliki hasil bahwa Customer satisfaction pada Mall mall memiliki pengaruh terhadap Minat Berkunjung Ulang secara signifikan dengan nilai uji $T$-statistic $>1.96$ yaitu 2.305 dan $P$ value sebesar 0.022 .

Penelitian ini mempunyai hasil yang menunjukkan bahwa Customer satisfaction berpengaruh signifikan terhadap Minat Berkunjung Ulang yang dimana hal ini sesuai dengan pendapat Matzler, Bailom, Hinterhuber, Renzl, dan Pichler (2004) di mana Customer satisfaction memiliki pengaruh signifikan dan meningkatkan Minat Berkunjung Ulang. Hasil penelitian ini juga dibuktikan. Menurut Bigné, Sánchez, (1999) kepuasan merupakan sebuah faktor penting untuk mempengaruhi Minat Berkunjung Ulang pengunjung.

Penelitian ini memiliki hasil yang membuktikan Customer satisfaction pada Mall berpengaruh secara signifikan terhadap Minat Berkunjung Ulang. Mall berupaya untuk meningkatkan Minat Berkunjung Ulang pengunjung. Dalam kualitas layanan ritel mall yang diciptakan Mall untuk terjadinya minat berkunjung ulang pengunjung adalah dengan memberikan pengunjung kepuasan dan rasa senang saat berkunjung ke mall dan mendapatkan apa yang mereka cari, mulai dari hiburan, barang belanjaan dan lainlain. Berdasarkan analisa Crosstabulation dimensi customer satisfaction dan Minat Berkunjung Ulang menunjukan kesetujuan pengunjung akan terciptanya customer satisfaction dan Minat Berkunjung Ulang pada Mall mall.

\section{KESIMPULAN DAN SARAN}

Berdasarkan hasil dari pembahasan, maka kesimpulan dalam penelitian ini adalah sebagai berikut: Retail Service Quality terbukti berpengaruh secara signifikan terhadap Perceived. Hal ini menunjukkan 
bahwa Retail Service Quality memiliki dampak terhadap Perceived Quality di Mall mall. Retail Service Quality berpengaruh secara signifikan terhadap Customer. Hal ini menunjukan bahwa Retail Service Quality memiliki dampak signifikan terhadap Customer satisfaction di Mall mall. Perceived Quality terbukti berpengaruh secara signifikan terhadap Customer satisfaction. Hal ini menunjukan bahwa Perceived Quality memiliki dampak terhadap Customer satisfaction di Mall mall.Perceived Quality berpengaruh secara signifikan terhadap Minat Berkunjung. Hal ini menunjukan bahwa Perceived Quality memiliki dampak signifikan terhadap Minat Berkunjung Ulang Mall. Customer satisfaction terbukti berpengaruh secara signifikan terhadap Minat Berkunjung. Hal ini menunjukan bahwa Customer satisfaction memiliki dampak signifikan terhadap Minat Berkunjung Ulang di Mall.

Penelitian ini dapat dilihat bahwa variable-variabel tersebut memiliki pengaruh satu sama lain. Seluruh variable ini menunjukan suatu pengaruh, namun berdasarkan path coefficient menunjukan bahwa dalam penelitian ini Perceived Qualitydan customer satisfaction memperkuat hubungan antara variable independen yang merupakan Retail Service quality terhadap variable dependen yang merupakan Minat Berkunjung Ulang. Jalur kritis di temukan pada Perceived Quality yang memperkuat Retail Service Quality dalam membentuk minat berkunjung ulang.

Berdasarkan hasil penelitian dan pembahasan di atas, peneliti akan mengajukan beberapa saran sebagai berikut:

a. Maintaning consistensy of facility quality and employee courtesy

Fasilitas mall dan kesopanan para karyawan mall menjadi titik penting bagi para pengunjung jika dilihat dari hasil kuesioner, dengan demikian Mall diharapkan dapat terus menjaga dan memberikan fasilitas yang berkualitas dan menjaga konsistensi karyawan dalam kesopanan mereka saat berinteraksi dengan pengunjung. Mall diharapkan melakukan quality control, training dan simulasi rutin per bulan agar kesopanan karyawan dapat terjaga dan konsisten tersampaikan kepada pengunjung. Untuk menjaga kualitas fasilitas yang diberikan Mall diharapkan menambah sofa tunggu yang pada beberapa titik masih belum ada (misal pada depan toilet pada semua lantai, didepan fashion area), karena bagi pengunjung hal-hal tersebut sangat diperhatikan dan sangat berpengaruh untuk menciptakan minat berkunjung ulang.

b. The importance of visitor needs regarding the restroom and the completeness of the product being sold
Toilet dan kelengkapan produk yang dijual menjadi salah dua faktor yang dipandang sangat penting untuk di improve dan dijaga konsistensi performanya bagi pengunjung. Dengan demikian Mall diharapkan untuk terus menjaga kebersihan dan melengkapi kebutuhan pengunjung saat menggunakan toilet didalam mall (perlak pada toilet khusus bayi, dll), dan juga diharapkan agar Mall dapat mengembangkan secara terus menerus dalam sektor produk-produk yang dijual didalam mall termasuk outlet-outlet yang berpartisipasi didalam mall karena kelengkapan produk yang dijual ini sangat membuat pengunjung senang.

\section{DAFTAR PUSTAKA}

Aaker, A. David, (1997) Manajemen Ekuitas Merek, Alih Bahasa: Aris Ananda, Spektrum Mitra Utama, Jakarta.

Aaker, D. A. (1991). Managing brand equity: Capitalizing on the value of a brand name. New York: Free Pres

Abdillah, W., \& Hartono, J. (2015). Partial Least Square (PLS) - Alternatif Stuctural Equation Modeling (SEM) dalam Penelitian Bisnis (Cetakan 1). Yogyakarta: Penerbit Andy

Asma Saleem, Abdul Ghafar, Muhammad Ibrahim, M. Y., \&amp; Ahmed, \&amp; N. (2015). Product Perceived Quality and Purchase Intention with Consumer Satisfaction. Retrieved from https://mail-attachment.googleusercontent.com/ attachment/u/1/?ui=2\&amp;ik=a2f8e3ba72\&am p;view=att\&amp;th=16247fb4b7fae2cc\&amp;at tid $=0.3 \& a m p ;$ disp=inline \&amp;realattid $=19 \mathrm{a} 21$ 7edcdd01ef9_0.1\&amp;safe=1\&amp;zw\&amp; saddbat=ANGjdJ94hj1OKjJtMfVhly_jrCxL7c NVQGUWLILcvSaHe0AOuws4163xtFUbecn WDFBNHR7YEv

Aziz, N.A., Ariffin, A.A.M., Omar, N.A., dan Chin Evin, 2012, "Examining the Impact of Visitors"e Emotions and Perceived Quality towards Satisfaction and Revisit Intention to Theme Parks (Kajian Kesan Emosi dan Tanggapan Kualiti Pengunjung terhadap Kepuasan dan Hasrat Berkunjung Semula ke Taman Tema)", Jurnal Pengurusan, 35, 97-109.

Bahram, Ali, Majid. 2012. An Analysis Of Brand Image Perceived Quality, Customer Satisfaction And Re-Purchace Intention In Iranian Departemant Stores. International Journal Of Business And Management, 7(6).

Baker, D. A., \& Crompton, J. L. (2000). Quality, satisfaction and behavioral intentions. Annals of tourism research, 27(3), 785-804. http://dx.doi. org/10.1016/S0160-7383(99)00108-5 
Bigne, J. E., Sanchez, M. I., \& Sanchez, J. (2001). Tourism image, evaluation variables and after purchase behaviour: Inter-relationship. Tourism Management, 22, 607-616.

Bou-Llusar, J. C., Camisón-Zornoza, C., \&amp; Escrig-Tena, A. B. (2001). Measuring the relationship between firm perceived quality and customer satisfaction and its influence on purchase intentions. Total Quality Management, 12(6), 719-734.

Cronin Jr. J.J, Tailor, SA, Measuring Service Quality: a Reexamination and Extension. Journal of Marketing Vol. 56,1992

Dabholkar, Pratibha, DayleThorpe and Joseph Rentz (1996). "A Measure of Service Quality for Retail Stores: Scale Development and Validation," Journal of the Academy of Marketing Science, Vol.24 (Winter), pp.3-16

Darmadi Durianto. 2004. Strategi Menaklukkan Pasar. Jakarta: PT. Gramedia.

Fornell, C. (1992). Satisfaction Barometer: The Swedish Experience. A National Customer Satisfaction Barometer: The Swedish Experience, 56(1), 6-21. Retrieved from https://www.jstor.org/stable/pdf/1252129.pdf

Hisam, M. W., Sanyal, S., \& Ahmad, M. (2016). The Impact of Service Quality on Customer Satisfaction: A Study on Selected Retail Stores in India. International Review of Management and Marketing, 6(4), 851-856.

Ihtiyar, A., Ahmad, F. S., \&amp; Osman, M. H. M. (2014). An Integrated Framework: Intercultural Competence, Service Quality and Customer Satisfaction in Grocery Retailing. Procedia- Social and Behavioral Sciences, 109(Ic), 492-496. https://doi.org/10.1016/j.sbspro.2013.12.495

Jamaluddin, J., \&amp; Ruswanti, E. (2017). Impact of Service Quality and Customer Satisfaction on Customer Loyalty: A Case Study in a Private Hospital in Indonesia. IOSR Journal of Business and Management, 19(5), 23-33. https://doi. org/10.9790/487X-1905012333

Kotler, P., \&amp; Keller, K. L. (2009). Marketing Management (13th ed.). Pearson.

Kozak, M. (2001), "Repeaters\&\#39; behavior at two distinct destinations", Annals of Tourism Research, Vol. 28 No. 3, pp. 784-807. http://www. academia.edu/6103046/REPEATERS_BEHAVI OR_AT_TWO_DISTINCT_DESTINATIONS
Lin, C.H. Effect of Cuisine Experience, Phychological Well-Being, and Self-Health Perception on the Revisit Intention of Hot Springs Tourist, Journal of Hospitality \& Tourism Research, P.122

Malhotra, N. K. (2004). Marketing research: an applied orientation $\left(4^{\text {th }}\right.$ Editio).New Jersey: Upper Saddle River.

Mardiyana, E., Wibowo, L. A., \&amp; Andari, R. (2012). Pengaruh Shopping Destination Strategy Terhadap Keputusan Berkunjung di Wisata Belanja Mall (Studi Banding pada Pengunjung Wisata Belanja Mall Kota Bandung yang terdiri dari Mall Cihampelas Walk dan Mall Paris Van Java). Manajemen Pemasaran Pariwisata FPIPS UPI, (2).

Matzler, K., Bailom, F., Hinterhuber, H. H., Renzl, B., \& Pichler, J. (2004). The asymmetric relationship between attribute-level performance and overall customer satisfaction: A reconsideration of the importance-performance analysis. Industrial Marketing Management, 33(4), 271277. doi:10.1016/S0019-8501(03)00055-5

Rangkuti, Freddy. 2004. The Power Of Brand : Teknik Mengelola Brand Equity Dan STrategi Pengembangan Merek. Jakarta: Gramedia Pustaka Utama.

Schiffman, Leon G., Kanuk, Leslie Lazar. 2007. Perilaku Konsumen. Alih Bahasa: Zoelkifli Kasip. Jakarta: Indeks

Simamora, B. (2002). Panduan riset perilaku konsumen. Jakarta.

Sinclair M.Thea dan Stabler Mike, 2007. The Economics of Tourism. Routledge, Canada

Sugiyono. (2007). Statistika untuk penelitian (Cetakan 10). Bandung: Alfabeta.

Sugiyono. (2009). Metode penelitian bisnis: pendekatan kuantitatif, kualitatif, dan R \& D (Cetakan 14). Bandung: Alfabeta.

Tjiptono, Fandy. 1996. Manajemen Jasa. Yogjakarta: Penerbit Andi.

Zeithaml, Valarie A., Mary Jo Bitner dan Dwayne D. Gremler. (2009). Services Marketing- Integrating Customer Focus Across The Firm (5 th ed). New York: McGraw-Hill.

Zhang, Z., Zhang, Z., \&amp; Law, R. (2013). Regional effects on customer satisfaction with restaurants. International Journal of Contemporary Hospitality Management, 25(5), 705-722. https://doi.org/10.1108/IJCHM-Aug-2012-0148. 